\title{
Lacaune ewes with subclinical mastitis: effects of intramammary application of
}

\section{própolis}

\author{
Ovelhas Lacaune com mastite subclínica: efeitos da aplicação intramamária de própolis \\ Ovejas Lacaune con mastitis subclínica: efectos de la aplicación intramamaria de propóleos
}

Received: 01/06/2021 | Reviewed: 01/07/2021 | Accept: 02/04/2021 | Published: 02/09/2021

Guilherme Luiz Deolindo

ORCID: https://orcid.org/0000-0001-9734-6902

Universidade do Estado de Santa Catarina, Brazil

E-mail: guilhermeluizd@outlook.com

Vitor Luiz Molosse

ORCID: https://orcid.org/0000-0003-3652-8088

Universidade do Estado de Santa Catarina, Brazil

E-mail: vitor.molosse@gmail.com

Amanda Dilda

ORCID: https://orcid.org/0000-0002-6802-1698

Universidade do Estado de Santa Catarina, Brazil

E-mail: amandaadilda@gmail.com

Lilian Kolling Girardini

ORCID: https://orcid.org/0000-0002-2891-7756

Universidade do Oeste de Santa Catarina, Brazil E-mail: lilian.kolling @unoesc.edu.br

Marcelo Vedovatto

ORCID: https://orcid.org/0000-0002-9050-6990 Universidade do Estado de Mato Grosso do Sul, Braszil E-mail: vedovatto@zootecnista.com.br

Aleksandro Schafer da Silva

ORCID: https://orcid.org/0000-0002-6940-6776 Universidade do Estado de Santa Catarina, Brazil E-mail: aleksandro_ss@yahoo.com.br

Denise Nunes Araujo

ORCID: https://orcid.org/0000-0001-9606-5447

Universidade do Estado de Santa Catarina, Brazil

E-mail: Denise.araujo@udesc.br

\begin{abstract}
The aim of this study was to evaluate the antimicrobial potential of the aqueous extract of green propolis in vitro against mastitis-causing and in vivo bacteria, evaluating the efficacy of treatment in Lacaune sheep. In the in vitro test, the minimum inhibitory concentration (MIC) was used; first, the MIC was obtained from the aqueous extract of green propolis for the strain of Staphylococcus. aureus ATCC 25523, defined as $1 \mathrm{mg} / \mathrm{ml}$. For bacterial agents isolated from sheep with mastitis (Staphylococcus epidermidis, Staphylococcus intermedius, Staphylococcus hyicus, Corynebacterium spp. and Acinetobacter spp.), The concentration of $10 \mathrm{mg} / \mathrm{ml}$ was determined, while for Streptococcus equinus, Escherichia coli, and hemolytic E. coli, also isolated from sheep with mastitis, the concentration capable of reducing bacterial growth was $100 \mathrm{mg} / \mathrm{ml}$. In the in vivo test, ten sheep were used, distributed in two treatments, five in the control group (CG) that received $2.5 \mathrm{ml}$ of saline (vehicle), and five in the treated group (GT) that received $2.5 \mathrm{ml}$ of aqueous (saline) propolis extract by the mammary route. The propolis dose tested $(0.1 \mathrm{~g} / \mathrm{ml})$ was not effective for the treatment of mastitis, because the sheep remained positive in the racket test (CMT). The main microorganism isolated in the cases of mastitis in this study was Staphylococcus epidermidis. These results are preliminary; however, at the tested dose, the aqueous extract of green propolis delivered by the mammary route had no curative effect of mastitis.
\end{abstract}

Keywords: Dairy sheep; Subclinical mastitis; Staphylococcus sp.; Green propolis; In vivo.

\section{Resumo}

O objetivo deste estudo foi avaliar o potencial antimicrobiano do extrato aquoso de própolis verde in vitro contra bactérias causadoras de mastite e in vivo, avaliando a eficácia do tratamento em ovinos da raça Lacaune. No teste in vitro, utilizou-se concentração inibitória mínima (CIM); primeiro, a CIM foi obtida a partir do extrato aquoso de própolis verde para a cepa de Staphylococcus aureus ATCC 25523, definido como $1 \mathrm{mg} / \mathrm{ml}$. Para agentes bacterianos isolados de ovelhas com mastite (Staphylococcus epidermidis, Staphylococcus intermedius, Staphylococcus hyicus, 
Corynebacterium spp. e Acinetobacter spp.) a concentração de $10 \mathrm{mg} / \mathrm{ml}$ foi determinada, enquanto para Streptococcus equinus, Escherichia coli e E. coli hemolítica a concentração capaz de reduzir o crescimento bacteriano foi de $100 \mathrm{mg} / \mathrm{ml}$. No teste in vivo, foram utilizados dez ovinos, distribuídos em dois tratamentos, cinco no grupo controle (CG) que receberam 2,5 ml de soro fisiológico (veículo), e cinco no grupo tratado (GT) que receberam $2,5 \mathrm{ml}$ de extrato aquoso de própolis (salina) via intramamária. A dose de própolis testada $(0,1 \mathrm{~g} / \mathrm{ml})$ não foi eficaz para o tratamento da mastite, pois as ovelhas permaneceram positivas no teste de raquete (CMT). O principal microrganismo isolado nos casos de mastite neste estudo foi o Staphylococcus epidermidis. Estes resultados são preliminares; no entanto, na dose testada, o extrato aquoso de própolis verde via intramamária não teve efeito curativo.

Palavras-chave: Ovelha leiteira; Mastite subclínica; Staphylococcus sp.; Própolis verde; In vivo.

\section{Resumen}

El objetivo de este estudio fue evaluar el potencial antimicrobiano del extracto acuoso de propóleos verdes in vitro contra las bacterias causantes de la mastitis e in vivo, evaluando la eficacia del tratamiento en ovejas lacaune. En la prueba in vitro, se utilizó una concentración mínima de inhibición (CIM); en primer lugar, CIM se obtuvo del extracto acuoso de propóleo verde para la cepa Staphylococcus aureus ATCC 25523, definida como $1 \mathrm{mg} / \mathrm{ml}$. Para agentes bacterianos aislados de ovejas con mastitis (Staphylococcus epidermidis, Staphylococcus intermedius, Staphylococcus hyicus, Corynebacterium spp. y Acinetobacter spp.) se determinó la concentración de $10 \mathrm{mg} / \mathrm{ml}$, mientras que para Streptococcus equinus, Escherichia coli y E coli Hemolitica. En la prueba in vivo, se utilizaron diez ovejas, distribuidas en dos tratamientos, cinco en el grupo de control (CG) que recibieron 2,5 ml de solución salina (vehículo), y cinco en el grupo tratado (TG) que recibieron $2,5 \mathrm{ml}$ de extracto acuoso de propóleo (salina) vía intramamaria. La dosis de propóleos probada $(0,1 \mathrm{~g} / \mathrm{ml})$ no fue eficaz para el tratamiento de la mastitis, ya que las ovejas siguieron siendo positivas en la prueba de ráquetica (CMT). El principal microorganismo aislado en casos de mastitis en este estudio fue Staphylococcus epidermidis. Estos resultados son preliminares; sin embargo, a la dosis probada, el extracto acuoso de propóleos verdes a través de intramamária no tuvo ningún efecto curativo.

Palabras clave: Ovejas lecheras; Mastitis subclínica; Staphylococcus sp.; Propóleos verdes; In vivo.

\section{Introduction}

In the Brazilian livestock industry, sheep farming is vying for a more prominent presence in the dairy sector (Rohenkohl et al., 2011). Milk is a vital food and a nutritional supplementation deployed in the fight against hunger (Haenlein, 2001). This is because, when compared with bovine milk, sheep's milk has higher levels of protein, calcium, and phosphorus, as well as high-quality fat [Souza et al., 2001; Revers et al., 2016). These authors reported that sheep milk facilitates digestion owing to its lower lipid chain lengths and its ability facilitate the activity of digestive enzymes, giving rise to greater nutrient use.

Nevertheless, sheep milk production can be significantly affected by mastitis, one of the main diseases that affect sheep. Mastitis is caused by pathogenic microorganisms that cause local inflammation, compromising mammary gland function (Santos et al., 2007). Mastitis directly affects milk production and quality, resulting in changes in milk composition (increased somatic cell counts and reduced fat and protein levels) resulting from inflammation Rovai et al., 2015). This phenomenon affects the industry as a whole as well as individual producers, changing the sensory characteristics of the final product and causing economic losses for dairy farms.

Microorganisms produce biofilms or sludge that hinder the action of allopathic products (Clutterbuck et al., 2007; López et al., 2010). As a result, the resistance against commonly used products for the treatment of mastitis increases. Against this background, there is a search for antimicrobial products with wide spectra of biological properties, for example, therapeutic agents with anti-inflammatory, antioxidant, and immunostimulating properties that may improve the health of the animal as a whole, not merely the mammary gland (Sperotto et al., 2012; Diarra et al., 2013; Wei et al., 2015). This has led to therapeutics based on bee products gaining prominence (Pereira et al., 2002). Nevertheless, it is of utmost importance to understand the mechanisms of bee products at the level of the animal, because their properties have already been tested and demonstrated at the laboratory level.

Propolis can be used to prevent disease, with good performance when used as a prophylactic for various diseases secondary to its antimicrobial properties, particularly flavonoids and terpenes (Teixeira et al., 2005). According to researchers, 
propolis is rich in artepillin C (3,5-diprenyl-4-hydroxycinnamic acid), which has immunomodulatory and anti-inflammatory properties (Paulino et al., 2008; Messerli et al., 2009; Fischer et al., 2010) useful in the treatment of udder infections. Propolis also has antioxidant properties (Cabral et al., 2009), an interesting and desirable factor when considering its use as a substitute for synthetic products. Neto et al. (2009) found positive results with the use of an aqueous extract of propolis against Staphylococcus sp. isolated from goats with mastitis, in which there were inhibition halos with diameters ranging from 8 to 15 $\mathrm{mm}$ (mean diameter $11.1 \pm 1.7 \mathrm{~mm}$ ).

The method of extracting propolis has a substantial influence on its antimicrobial activity; for example, researchers evaluated several solvents for the extraction of propolis and found that with the water, olive oil, coconut oil, and polyethylene glycol, the proportions extracted from flavonoids were $0.33 \%, 0.22 \%, 0.20-0.25 \%$, and $0.55 \%$, respectively (Pujirahayu et al., 2014). According to Xu et al. (2009) the most commonly used solvents for the extraction of propolis are ethanol and methanol; however, water is also used, because some propolis substances are soluble only in water.

Because of the great relevance that mastitis has in the sheep milk production chain, in the present study, we aimed to evaluate the antimicrobial potential of aqueous green propolis extract in vitro against mastitis-causing bacteria and in vivo, evaluating the effectiveness of treatment in sheep from the Lacaune breed.

\section{Materials and Methods}

This research had an exploratory and quantitative nature (Pereira et al., 2018). The project was approved by the Ethics Committee for Animal Well-Being at the State University of Santa Catarina-UDESC, under protocol no 8954200520.

\subsection{Production and composition of propolis}

Propolis used was purchased from a commercial apiary. The extraction was carried out according to a methodology adapted from (Kubilene et al., 2015). Crude propolis was ground in a porcelain mortar with the aid of liquid nitrogen. The preparation condition included $10 \mathrm{~g}$ of propolis, $100 \mathrm{ml}$ of water, and $20 \mathrm{~g}$ of polyethylene glycol (PEG) 400, subjected to high pressure at $120{ }^{\circ} \mathrm{C}$ for 5 minutes in a horizontal-type autoclave. After extraction, the extract was filtered on $\mathrm{n}^{\circ} 1$ Whatman paper. The solution was stored in an amber bottle, protected from light.

The determination of total phenolic compounds (TPC) was performed using the Folin-Ciocalteu colorimetric method modified by Bonoli et al. (2004). A $0.5-\mathrm{ml}$ aliquot was mixed with $0.5 \mathrm{ml}$ of Folin-Ciocalteu reagent and was stirred for 1 minute. Then, $2 \mathrm{ml}$ of sodium carbonate (20\%) was added to the mixture and stirred for $30 \mathrm{~s}$. After $2 \mathrm{~h}$ of incubation, the absorbance was read at $750 \mathrm{~nm}$. The standard curve was prepared using various concentrations of gallic acid in methanol. The concentration of TPC was calculated using an equation derived from the standard curve of gallic acid (expressed as mg of gallic acid equivalent per $\mathrm{g}$ of dry sample; $\mathrm{mg} \mathrm{GAE} / \mathrm{g}$ ). The data were expressed as the mean $\pm \mathrm{SD}$ of three experiments.

\subsection{Minimum inhibitory concentration (MIC)}

The inoculum preparation was performed with Staphylococcus aureus ATCC 25523 and with the agents isolated from the milk S. epidermidis, S. intermedius, S. hyicus, Streptococcus equinus, E. coli, and hemolytic E. coli culture, in $5 \mathrm{ml}$ of brain heart infusion broth (BHI) and the Acinetobacter spp. in $5 \mathrm{ml}$ of Tryptone Soya Broth (TSB) incubated at $37 \pm 1{ }^{\circ} \mathrm{C}$ for 24 hours or until turbidity corresponding to 0.5 on the McFarland scale was obtained. Corynebacterium spp. was inoculated in brain and heart infusion broth (BHI) + Tween $80(1 \%)$ incubated at $37 \pm 1^{\circ} \mathrm{C}$ for 48 hours.

The minimum inhibitory concentration (MIC) performed in accordance with the Institute of Clinical and Laboratory Standards (2008), was determined by serial dilution of the aqueous propolis extract in Mueller-Hinton broth in 96-well sterile microplates, using $150 \mu \mathrm{l}$ of diluted solution and $10 \mu \mathrm{l}$ of inoculum. The plates were incubated for 24 hours at $37 \pm 1^{\circ} \mathrm{C}$; after 
this period, $15 \mu \mathrm{l}$ of $1 \%$ 2,3,5-triphenyltetrazolium chloride solution was added as a developer. The production of red color after 3 hours of incubation indicates microbial growth. The minimum inhibitory concentration was defined as the lowest concentration of propolis that did not show visible growth after incubation.

\subsection{Animals, feeding and experimental design}

The experiment was carried out in Cabanha Chapecó, located in Chapecó, SC, Brazil. Ten Lacaune ewes were selected at random, standardized by age, sex, and race, during a lactation period of approximately 90 days. The animals were divided into two groups: five animals for the control group (GC) that received $2.5 \mathrm{ml}$ of saline solution and five animals in the treated group (GT) that received $2.5 \mathrm{ml}$ of the extract; through the intra-mammary route. The applications occurred immediately after milking at 12 -h intervals, totaling three applications. All animals had a positive diagnosis on the racket test (California Mastitis Test - CMT) and had a history of subclinical mastitis for more than 30 days; therefore, they were already in feedlot isolated from the rest of the herd. No animal had systemic involvement such as fever, loss of appetite, apathy, dyspnea, or difficulty in walking. The confinement was carried out in a covered shed, with wood shavings and access to water ad libitum. The animals were fed twice a day (at 8:00 am and 5:00 pm), based on $400 \mathrm{~g}$ of concentrate (18\% crude protein), 3.5 $\mathrm{kg}$ of corn silage, and hay at will.

\subsection{Milk measurement}

The milking of the animals was mechanized and performed twice daily (at 07:30 and 17:00 hours). The individual volumetric verification of milk was performed for all animals, obtained using a "Milk Meter" type meter (True Test ${ }^{\circledR}$, Auckland, New Zealand), measuring the volume produced at the morning and afternoon milking.

\subsection{Sample collection}

From day 1 to day 8 of the experiment, and later on days 14 and 21, milk samples were collected from each animal's teats in sterile flasks, after cleaning the roof (papilla) with $70 \%$ alcohol and disposing of the first three jets to the microbial isolation and total bacterial count. In the same period, $40 \mathrm{~mL}$ of milk was collected from each animal using WB HI/Pullout Tru-Test@ equipment, which allows the collection of a milk sample from the complete milking of the animal.

Before the morning milking, still fasting, the animals were manually restrained to collect blood samples, via the jugular vein using vacuolized tubes. A volume of $4 \mathrm{~mL}$ of blood was placed in a tube containing EDTA (ethylenediamine tetraacetic acid) for the performance of erythrogram and leukogram, and another $4 \mathrm{~mL}$ were placed in tubes without anticoagulant to obtain the serum for biochemical analysis.

\subsection{Hemogram and serum biochemistries}

The total count of erythrocytes and leukocytes, as well as the hemoglobin concentration, was performed using a semiautomatic cell counter (model CELM CC530). Differential leukocyte counting was performed using blood smears stained by the method of Romanowsky (1891) and visualized under optical microscopy. The hematocrit was obtained using capillary tubes for microhematocrit centrifuging at $11,000 \mathrm{~g}$ for 5 minutes.

The tubes without anticoagulant were centrifuged (5100 $\mathrm{g}$ for 10 minutes) to separate the serum. The supernatants were transferred to $1.5-\mathrm{ml}$ microtubes, identified and stored at $-20^{\circ} \mathrm{C}$ until analysis. In these samples, the levels of total proteins, albumin, and urea were measured using a semiautomatic analyzer (Bio-2000 BioPlus ${ }^{\circledR}$ ) and commercial kits $\left(\right.$ Analisa $\left.{ }^{\circledR}\right)$. Globulin values were calculated as the difference between total protein and albumin levels. 


\subsection{Milk analyses}

\subsubsection{Centesimal composition and somatic cell counts}

The proximate composition (fat, protein, lactose, and total dry extract) was determined using an infrared analyzer (LactoStar Funke Gerber ${ }^{\circledR}$ ) and somatic cell counts (SCC) were made using a digital counter (Ekomilk Scan Somatic Cells Analyzer®).

\subsubsection{Total bacterial counts (TBC)}

Plate count agar (PCA) was used to perform the TBC; $100 \mu \mathrm{L}$ of milk, previously diluted in peptone water to 10 -fold concentration, was inoculated into sterile Petri dishes using a Drigalski loop, following the spread plate method. Then, the plates were incubated in a bacteriological oven at $37 \pm 1^{\circ} \mathrm{C}$ for 48 hours for later reading. The samples were kept refrigerated until the moment of the analysis.

\subsubsection{Identification of causative agents}

The samples were cultured on blood agar supplemented with 5\% defibrinated sheep blood, MacConkey agar and Sabouraud agar using the striation technique. The plates were incubated at $37{ }^{\circ} \mathrm{C}$ for 24 to 72 hours, and the microorganisms were identified according to the morpho-tinting characteristics presented according to the description of the National Mastitis Council (2004) and Markey et al. (2013).

\subsection{Racket test (California Mastitis Test - CMT)}

The test was carried out on days 1, 7, 14, and 21 of the experiment, using a white racket with four compartments and reagent type CMT - Solution (TADABRAS®). After cleaning the teats with $70 \%$ alcohol and removing the three first jets. The results were interpreted as positive or negative.

\subsection{Statistical analysis}

The animal was considered the experimental unit for all analyses. All dependent variables were tested for normality using Univariate procedure of SAS (SAS Inst. Inc., Cary, NC, USA; version 9.4); only total bacterial counts and somatic cell counts were not normally distributed and where transformed. Then, the binomial data of CMT (positive or negative) were analyzed using the GLIMMIX procedure and all others data used the MIXED procedure of SAS. In both procedures, the Satterthwaite approximation was used to determine the denominator degrees of freedom for the test of fixed effects. All variables were analyzed as repeated measures. The results of milk production ( $\mathrm{mL} / \mathrm{milking})$, milk composition and SCC were tested for fixed effects of treatment, day, milking, and all possible interaction, and using animal(treatment) as random variables, and animal(treatment) as subject. The results of hemogram, serum biochemistry, and milk microbiological count variables were tested for fixed effects of treatment, day, and treatment $\times$ day, and using animal(treatment) as the random variable and animal(treatment) as the subject. The compound symmetric covariance structure was selected for the milk concentration of fat and lactose. The Toeplitz covariance structure was selected for hematocrit, and eosinophils and the firstorder autoregressive covariance structure was selected for all other variables. The covariance structures were selected according to the lowest Akaike information criterion. Means were separated using PDIFF and all results were reported as LSMEANS followed by SEM. Significance was defined when $P \leq 0.05$, and tendency when $P>0.05$ and $\leq 0.10$.

\section{Results}

\subsection{Total phenolic compounds (TPC)}


The content of total phenolic compounds present in the aqueous extract of propolis was $767.08 \pm 1.8$ mg equivalent to gallic acid/ml.

\subsection{Isolated bacterial agents}

From the milk samples collected, we obtained bacterial growth of Staphylococcus epidermidis $(\mathrm{n}=29$, corresponding to $46 \%$ of the isolated agents), Staphylococcus hyicus ( $\mathrm{n}=11$, corresponding to $17 \%$ of the isolated agents), Escherichia coli ( $\mathrm{n}=10$, corresponding to $16 \%$ of the isolated agents), hemolytic E. coli ( $\mathrm{n}=5$, corresponding to $8 \%$ of the isolated agents), Staphylococcus intermedius $(\mathrm{n}=4$, corresponding to $6 \%$ of the isolated agents), Corynebacterium spp. ( $\mathrm{n}=2$, corresponding to $3 \%$ of the isolated agents), Acinetobacter spp. ( $\mathrm{n}=1$, corresponding to $2 \%$ of the isolated agents), yeast ( $\mathrm{n}=1$, corresponding to $2 \%$ of the isolated agents), and Streptococcus equinus ( $\mathrm{n}=1$, corresponding to $2 \%$ of the isolated agents) (Table 1$)$.

Table 1: Microorganisms isolated from the right (D) and left (E) teats in the 80 sheep milk samples Lacaune with subclinical mastitis. ${ }^{1}$ Right $(\mathrm{R})$ and left $(\mathrm{L})$ teat.

\begin{tabular}{|c|c|c|c|c|c|}
\hline \multirow[b]{2}{*}{ Sh eep } & \multirow[b]{2}{*}{${ }^{1}$ Teat } & \multicolumn{4}{|c|}{ Agents isolated } \\
\hline & & Day 1 & Day 7 & Day 14 & Day 21 \\
\hline \multirow[t]{2}{*}{1} & $\mathrm{D}$ & Escherichia coli & Staphylococcus epidermidis & Staphylococcus epidermidis & Stophylococcus epidermidis \\
\hline & $\mathrm{E}$ & Escherichiacoli & No bacterial growth & No bacterial growth & Corynebacterium spp. \\
\hline \multirow[t]{2}{*}{2} & $\mathrm{D}$ & Escherichia coli & No bacterial growth & No bacterial growth & No bacterial growth \\
\hline & $\mathrm{E}$ & Streptococclis equinus & Staphylococcus hyicus & No bacterial growth & No bacterial growth \\
\hline \multirow[t]{2}{*}{3} & $\mathrm{D}$ & Escherichia coli. & No bacterial growth & Staphylococcus epidermidis & Staphylococcus epidermidis \\
\hline & $\mathrm{E}$ & Staphylococcus epidermidis & No bacterial growth & Stophylococcus hyicus & Stophylococcus epidermidis \\
\hline \multirow[t]{2}{*}{4} & $\mathrm{D}$ & S. epidermidis and S. hyicus & Stcphylococcus epidermidis & Staphylococcus epidermidis & No bacterial growth \\
\hline & $\mathrm{E}$ & Escherichia coli. & Stcphylococcus intermedius & Staphylococcus epidermidis & Stophylococcus epidermidis \\
\hline \multirow[t]{2}{*}{5} & $\mathrm{D}$ & E. coli and Hemolytic E. coli & Stcphylococcus epidermidis & Staphylococcus epidermidis & Stophylococcus intermedius \\
\hline & $\mathrm{E}$ & E. coli and Hemolytic E. coli & Staphylococcus epidermidis & Yeast & No bacterial growth \\
\hline \multirow[t]{2}{*}{6} & $\mathrm{D}$ & Acinetobacter spp. & No bacterial growth & No bacterial growth & No bacterial growth \\
\hline & $\mathrm{E}$ & Staphylococcus epidermidis & No bacterial growth & $\begin{array}{l}\text { S. epidermidis and } \\
\text { Corynebacterium spp. }\end{array}$ & No bacterial growth \\
\hline \multirow[t]{2}{*}{7} & $\mathrm{D}$ & S. hyicus and Hemolytic E. coli & No bacterial growth & No bacterial growth & No bacterial growth \\
\hline & $\mathrm{E}$ & $\begin{array}{l}\text { S. epidermidis and Hemolytic E. } \\
\text { coli }\end{array}$ & Stophylococcus epidermidis & No bacterial growth & Stophylococcus epidermidis \\
\hline \multirow[t]{2}{*}{8} & $\mathrm{D}$ & S. epidermidis and E. coli & Staphylococcus epidermidis & Stophylococcus hyicus & Staphylococcus epidermidis \\
\hline & $\mathrm{E}$ & Hemolytic E coli & No bacterial growth & Staphylococcus epidermidis & Staphylococcus epidermidis \\
\hline \multirow[t]{2}{*}{9} & $\mathrm{D}$ & Escherichia coli. & Staphylococcus epidermidis & No bacterial growth & Stophylococcus intermedius \\
\hline & $\mathrm{E}$ & Staphylococcus epidermidis. & No bacterial growth & Staphylococcus hyicus & Staphylococcus epidermidis \\
\hline \multirow[t]{2}{*}{10} & $\mathrm{D}$ & Stophylococcus hyicus & Stcphylococcus intermedius & Staphylococcus epidermidis & Stophylococcus intermedius \\
\hline & $\mathrm{E}$ & S. hyicus and E. coli & Staphylococcus hyicus & Stophylococcus hyicus & Staphylococcus hyicus \\
\hline
\end{tabular}

Source: Authors.

\subsection{Antimicrobial activity of propolis extract against isolates}

The minimum inhibitory concentration (MIC) obtained from the aqueous extract of green propolis for $S$. aureus ATCC 25523 was $1 \mathrm{mg} / \mathrm{ml}$. For isolated bacterial agents S. epidermidis, S. intermedius, S. hyicus, Corynebacterium spp. and Acinetobacter spp., a concentration of $10 \mathrm{mg} / \mathrm{ml}$ was obtained, while for Streptococcus equinus, E. coli, and hemolytic E. coli, a concentration of $100 \mathrm{mg} / \mathrm{ml}$ capable of reducing bacterial growth was obtained.

\subsection{Milk production, composition and quality}

No effects of treatment $\times$ day $\times$ milking were detected $(P>0.48)$ for any variable of milk production and composition (Table 2). Further, no effects of treatment $\times$ day $(P>0.39)$ or treatment $(P>0.33)$ were detected for CMT, milk production, milk concentration of fat and minerals, density, or SCC (Table 2$)$. However, effects of treatment $\times$ day $(P \leq 0.05)$ but not treatment $(P>0.20)$ were detected for milk concentration of protein, lactose, and solids-non-fat, and treated animals had lower concentrations of these on d 2, 4, and 14, compared to control animals (Table 2). 
Table 2. Milk production and composition of Lacaune ewes with subclinical mastitis receiving intramammary application of green propolis.

\begin{tabular}{|c|c|c|c|c|c|c|}
\hline \multirow[b]{2}{*}{ Variables $^{1}$} & \multicolumn{2}{|c|}{ Treatments $^{2}$} & \multirow[b]{2}{*}{ SEM } & \multicolumn{3}{|c|}{$P$-value } \\
\hline & Control & Treated & & Treat & $\begin{array}{c}\text { Treat } x \\
\text { day }\end{array}$ & $\begin{array}{c}\text { Treatment } \times \text { day } \times \\
\text { milking }\end{array}$ \\
\hline CMT (\% of positive) & 90.00 & 90.00 & 0.08 & 0.99 & 0.44 & - \\
\hline Production (mL/milking) & 415.00 & 443.33 & 74.97 & 0.80 & 0.39 & 0.48 \\
\hline Production (mL/day) & 830.00 & 886.67 & 149.94 & 0.80 & 0.39 & - \\
\hline \multicolumn{7}{|l|}{ Milk composition } \\
\hline Protein $(\mathrm{g} / \mathrm{kg})$ & & & & 0.23 & 0.05 & 0.99 \\
\hline d 1 & 3.89 & 3.90 & 3.89 & & & \\
\hline $\mathrm{d} 2$ & $4.03^{\mathrm{a}}$ & $3.79^{\mathrm{b}}$ & 4.03 & & & \\
\hline d 3 & 3.94 & 3.78 & 3.94 & & & \\
\hline $\mathrm{d} 4$ & $4.24^{\mathrm{a}}$ & $4.01^{\mathrm{b}}$ & 4.24 & & & \\
\hline d 5 & 4.18 & 4.01 & 4.18 & & & \\
\hline d 6 & 4.09 & 4.19 & 4.09 & & & \\
\hline $\mathrm{d} 7$ & 4.11 & 4.06 & 4.11 & & & \\
\hline $\mathrm{d} 8$ & 4.12 & 4.02 & 4.12 & & & \\
\hline d 14 & $4.37^{\mathrm{a}}$ & $4.06^{\mathrm{b}}$ & 4.37 & & & \\
\hline $\mathrm{d} 21$ & 4.23 & 4.02 & 4.23 & & & \\
\hline Fat $(\mathrm{g} / \mathrm{kg})$ & 6.99 & 7.37 & 0.37 & 0.49 & 0.49 & 0.99 \\
\hline Lactose $(\mathrm{g} / \mathrm{kg})$ & & & & 0.20 & 0.05 & 0.93 \\
\hline d 1 & 5.52 & 5.56 & 0.13 & & & \\
\hline $\mathrm{d} 2$ & $5.70^{\mathrm{a}}$ & $5.39^{\mathrm{b}}$ & 0.13 & & & \\
\hline d 3 & 5.58 & 5.38 & 0.13 & & & \\
\hline $\mathrm{d} 4$ & $6.02^{\mathrm{a}}$ & $5.69^{\mathrm{b}}$ & 0.13 & & & \\
\hline d 5 & 5.91 & 5.69 & 0.13 & & & \\
\hline d 6 & 5.78 & 5.93 & 0.13 & & & \\
\hline $\mathrm{d} 7$ & 5.82 & 5.74 & 0.13 & & & \\
\hline $\mathrm{d} 8$ & 5.82 & 5.68 & 0.13 & & & \\
\hline d 14 & $6.16^{\mathrm{a}}$ & $5.76^{\mathrm{b}}$ & 0.13 & & & \\
\hline $\mathrm{d} 21$ & 5.97 & 5.69 & 0.13 & & & \\
\hline Solids-not-fat $(\mathrm{g} / \mathrm{kg})$ & & & & 0.27 & $\mathbf{0 . 0 3}$ & 0.09 \\
\hline $\mathrm{d} 1$ & 10.46 & 10.53 & 0.26 & & & \\
\hline $\mathrm{d} 2$ & $10.89 a$ & $10.25 b$ & 0.26 & & & \\
\hline d 3 & 10.68 & 10.22 & 0.26 & & & \\
\hline $\mathrm{d} 4$ & $11.45 \mathrm{a}$ & $10.84 \mathrm{~b}$ & 0.26 & & & \\
\hline d 5 & 11.26 & 10.86 & 0.26 & & & \\
\hline d 6 & 11.01 & 11.35 & 0.26 & & & \\
\hline $\mathrm{d} 7$ & 11.08 & 10.98 & 0.26 & & & \\
\hline $\mathrm{d} 8$ & 11.09 & 10.85 & 0.26 & & & \\
\hline d 14 & $11.78 \mathrm{a}$ & $10.97 b$ & 0.26 & & & \\
\hline $\mathrm{d} 21$ & 11.38 & 10.84 & 0.26 & & & \\
\hline Density & 10083.00 & 9739.07 & 234.46 & 0.33 & 0.50 & 0.74 \\
\hline
\end{tabular}


Research, Society and Development, v. 10, n. 2, e18210211709, 2021

(CC BY 4.0) | ISSN 2525-3409 | DOI: http://dx.doi.org/10.33448/rsd-v10i2.11709

\begin{tabular}{lccccccc}
\hline & & & & & & \\
Minerals $(\mathrm{g} / \mathrm{kg})$ & 0.82 & 0.84 & 0.03 & 0.64 & 0.63 & 0.93 \\
$\mathrm{SCC}\left(\mathrm{x} 10^{3} / \mathrm{mL}\right)$ & 213.90 & 242.30 & 44.10 & 0.66 & 0.60 & 0.52 \\
\hline
\end{tabular}

${ }^{1} \mathrm{SCC}$, somatic cell count. CMT, California Mastitis Test.

${ }^{2}$ Control and Treated represents $2.5 \mathrm{ml}$ of saline solution and $2.5 \mathrm{ml}$ of aqueous propolis extract, respectively.

a-b Differs $(P \leq 0.05)$ between treatments.

Source: Authors.

\subsection{Hemogram, Bioquímica Sérica and Contagem Bacteriana Total}

No effects of treatment $\times$ day $(P \geq 0.14)$ and treatment $(P \geq 0.31)$ were detected for hemogram or serum biochemistry variables (Table 3 ) and also for milk microbiological counts (Table 4).

Table 3. Hematological and biochemical variables of Lacaune ewes with subclinical mastitis receiving intramammary application of propolis.

\begin{tabular}{|c|c|c|c|c|c|}
\hline \multirow{2}{*}{ Variables } & \multicolumn{2}{|c|}{ Treatments $^{1}$} & \multirow{2}{*}{ SEM } & \multicolumn{2}{|c|}{$P$-value } \\
\hline & Control & Treated & & Treat & Treat $\times$ day \\
\hline \multicolumn{6}{|l|}{ Hemogram } \\
\hline Erythrocytes $\left(\mathrm{x} 10^{6} \mu \mathrm{L}\right)$ & 9.77 & 10.77 & 0.65 & 0.31 & 0.47 \\
\hline Hematocrit (\%) & 34.95 & 37.96 & 2.01 & 0.32 & 0.27 \\
\hline Hemoglobin (g/dL) & 11.65 & 12.46 & 0.66 & 0.41 & 0.92 \\
\hline Leukocytes $\left(\mathrm{x} 10^{3} \mu \mathrm{L}\right)$ & 67.41 & 81.99 & 11.24 & 0.38 & 0.55 \\
\hline Neutrophils $\left(\mathrm{x} 10^{3} \mu \mathrm{L}\right)$ & 34.88 & 34.51 & 6.15 & 0.97 & 0.33 \\
\hline Lymphocytes $\left(\mathrm{x} 10^{3} \mu \mathrm{L}\right)$ & 30.46 & 41.37 & 8.15 & 0.37 & 0.16 \\
\hline Monocytes $\left(\mathrm{x} 10^{3} \mu \mathrm{L}\right)$ & 0.88 & 1.24 & 0.35 & 0.46 & 0.93 \\
\hline Eosinophils $\left(\mathrm{x} 10^{3} \mu \mathrm{L}\right)$ & 1.19 & 1.85 & 0.47 & 0.35 & 0.23 \\
\hline \multicolumn{6}{|l|}{ Biochemistry } \\
\hline Total Protein $(\mathrm{g} / \mathrm{dL})$ & 8.40 & 8.76 & 0.45 & 0.59 & 0.57 \\
\hline Albumin (g/dL) & 3.22 & 3.02 & 0.20 & 0.51 & 0.42 \\
\hline Globulin (g/dL) & 5.19 & 5.73 & 0.44 & 0.40 & 0.23 \\
\hline Urea $(\mathrm{mg} / \mathrm{dL})$ & 37.90 & 32.40 & 6.01 & 0.54 & 0.65 \\
\hline
\end{tabular}

${ }^{1}$ Control and Treated represents $2.5 \mathrm{ml}$ of saline solution and $2.5 \mathrm{ml}$ of aqueous propolis extract, respectively.

${ }^{\mathrm{a}-\mathrm{b}}$ Differs $(P \leq 0.05)$ between treatments.

Source: Authors. 
Table 4. Milk microbiological count of Lacaune ewes with subclinical mastitis receiving intramammary application of green propolis.

\begin{tabular}{lcccccc}
\hline \multirow{2}{*}{ Variables } & \multicolumn{2}{c}{ Treatments $^{1}$} & & \multicolumn{2}{c}{$\boldsymbol{P}$-value } \\
\cline { 2 - 3 } & Control & Treated & & & Treat & Treat $\times$ day \\
\hline Right teat $\left(\times 10^{-1} \mathrm{UFC} / \mathrm{mL}\right)$ & 200.07 & 263.20 & & 94.51 & 0.65 & 0.36 \\
Left teat $\left(\mathrm{x} 10^{-1} \mathrm{UFC} / \mathrm{mL}\right)$ & 271.49 & 324.09 & & 71.54 & 0.62 & 0.14 \\
Both teats, mean $\left(\mathrm{x} 10^{-1} \mathrm{UFC} / \mathrm{mL}\right)$ & 235.78 & 293.65 & & 75.97 & 0.60 & 0.22 \\
\hline
\end{tabular}

${ }^{1}$ Control and Treated represents $2.5 \mathrm{ml}$ of saline solution and $2.5 \mathrm{ml}$ of aqueous propolis extract, respectively. $P>0.05$ no difference between groups.

Source: Authors.

\section{Discussion}

The microorganisms most found in the milk samples in this study were from the genus Staphylococcus sp. According to the literature, coagulase-negative Staphylococci (CNS) are the most common causative agents of subclinical mastitis in dairy ruminants (Deinhofer \& Pernthaner 1995; Contreras et al., 1997; Arznabarreta et al., 2002). In addition to the prevalent isolation of CNS, Corynebacterium sp. was found in two samples. Subclinical mastitis caused by this agent does not cause any major problems, as it allows rapid diagnosis and treatment by visualizing the increase in CCS, unlike infection caused by the Staphylococcus sp. which cause destruction of the cells of the glandular epithelium, causing significant losses in milk production (Barkema et al., 2006).

In a study on subclinical mastitis in Lacaune ewes in Western Santa Catarina, 92\% of the isolates were Staphylococcus sp. and only 8\% were Corynebacterium sp. (Alba et al., 2019). In the present study, strains of E. coli and hemolytic E. coli were also isolated. According to Radostits et al. (2000), infections by microorganisms of this genus are transmitted through the feces of the animals, and probably contaminate the mammary gland of the sheep when they lie down in the stall immediately after milking, because the orifice and canal of the teat are still dilated, or "open." According to Farshad et al. (2012), the presence of this microorganism in raw milk and dairy products is serious, as it can cause diseases such as uremic hemolytic syndrome, hemorrhagic colitis, and bloody diarrhea; this is why we seek to reduce bacterial contamination of milk to the greatest extent possible. In a recent study with cattle, 14 isolates from milk were identified as E. coli (Ismail \& Abutarbush, 2020), a zoonotic bacterium that needs to be under constant surveillance.

Although the propolis used in this study showed positive results in reducing bacterial growth in in vitro tests, it was not possible to observe the same result when applied to the animals' mammary glands. In the case of its action against $E$. coli, for example, we found a higher concentration of product required to inhibit growth. According to Sforcin et al. (2000), gramnegative bacteria have lipid content and greater chemical complexity in the cell wall that limits the action of propolis. However, regarding Staphylococcus sp., researchers found that $1 \mathrm{mg} / \mathrm{ml}$ had a bactericidal effect against a strain of S. aureus (Santana et al., 2012), as found in the in vitro tests here. A study using aqueous and ethanol extract of propolis against sheep milk isolates found that the concentration of $0.05 \mathrm{mg} / \mathrm{ml}(50 \mu \mathrm{g} / \mathrm{ml})$ had strong in vitro activity against strains of Staphylococcus sp. (Santos Neto et al., 2009). Researchers found that higher concentrations against anaerobic gram-positive bacteria $(1,024 \mu \mathrm{g} / \mathrm{ml})$ may be effective (Santos et al., 2002), while in another study, it was found that the inhibitory concentration against $S$. aureus was $3,650 \mu \mathrm{g} / \mathrm{ml}$ (Miorin et al., 2003), both using ethanol extract of propolis. This fluctuation in the inhibitory concentrations against strains of the same genus can be explained by the distinct resistance that bacteria can present, as well as the activity of propolis, which, regardless of its extraction mode, has a seasonal dependence, because in each season it can present changes in its compounds and this may be reflected in its antimicrobial action (Lu et al., 2005). 
In the present study, the proximate composition of milk was not altered by the treatment with the aqueous extract of propolis. Furthermore, according to the Technical Regulation of Production, Identity and Quality of raw sheep milk (2019) from ABCOL (Brazilian Breeders Association Dairy Sheep), the parameters were in accordance with the recommended values. The absence of a negative control group (free of mastitis) in this study limits our interpretation, that is, whether the milk composition was affected by local disease. In a recent study conducted on the same farm (Alba et al., 2019), lower levels of protein, fat and total solids were obtained, and milk production was lower for the group of animals with mastitis when compared to healthy animals of the control group. This was also observed in another study conducted on the same property, where the animals had lower levels of fat, protein, lactose, non-fat solids and total solids, as well as a milk production difference of 0.1-0.4 L/ewe/day when evaluated in relation to those who received some type of treatment (Jaguezeski et al., 2018). Regarding biochemical and hematological variables, we did not obtain significant results between the groups; however, if we evaluate the data obtained and relate it to what mastitis changes in terms of animal health, we note that the numbers of defense cells changed, that is, they increased; this is similar to the results described by Alba et al. (2019). Corroborating the findings of our study, Ebrahimi et al. (2014) commented that, in the face of invasion of microorganisms in the mammary gland, the number of these cells, mainly neutrophils, rises in order to combat the infectious process. Pinheiro Junior et al. (2006) found that, in case of acute mastitis affected by Corynebacterium pseudotuberculosis, there were elevated leukocyte numbers, in view of the adrenocortical substances produced at the beginning of the infection. We believe that as subclinical mastitis became chronic in the sheep used in our study, the phase of metabolic disorders had already occurred; that is, the sheep were able to adapt to the presence of microorganisms; alternatively, the infection was mild, unable to alter the metabolism of protein, lipids, and carbohydrates in the blood of these animals.

This was a preliminary study, which involved only one dose of propolis, as well as a small number of sheep with chronic subclinical mastitis. In future studies by our research group, we intend to evaluate a greater number of doses, as well as the effect of red propolis extracted with water solvent against cases of mastitis in vitro, and, in case of success, in vivo.

\section{Conclusion}

Sheep with mastitis had high total leukocyte counts as a result of increases in neutrophils and lymphocytes. The main microorganism isolated in the cases of mastitis in this study was Staphylococcus epidermidis. The aqueous extract had a strong antimicrobial effect in vitro against strains isolated from cases of mastitis. In vivo, the dose of aqueous propolis used had no curative effect, just as there was no influence on milk production or quality, or on sheep health.

\section{Conflict of interest}

The authors declare no conflict of interest.

\section{References}

Alba, D. F., da Rosa, G., Hanauer, D., Saldanha, T. F., Souza, C. F., Baldissera, M. D. \& Da Silva, A. S. (2019). Subclinical mastitis in Lacaune sheep: Causative agents, impacts on milk production, milk quality, oxidative profiles and treatment efficacy of ceftiofur. Microbial Pathogenesis, $137,103$.

Ariznabarreta, A., Gonzalo, C. \& San Primitivo, F. (2002). Microbiological quality and somatic cell count of ewe milk with special reference to staphylococci. Journal of Dairy Science, 85, 1370-1375.

Associação Brasileira de Criadores de Ovinos Leiteiros (ABCOL). (2019). Regulamento técnico de produção, identidade e qualidade de leite de ovelha cru. https://www.gov.br/agricultura/pt-br/assuntos/camaras-setoriais tematicas/documentos/camaras-setoriais/caprinos-e-ovinos/2019/57a-ro/pedido-de-validacaortiq-leite-ovino.pdf

Barkema, H. W., Schukken, Y. H. \& Zadoks, R. N. (2006). Invited Review: the role of cow, pathogen, and treatment regimen in the therapeutic success of bovine Staphylococcus aureus mastitis. Journal of Dairy Science, 89, 1877-1895. 
Bonoli, M., Verardo, V., Marconi, E. \& Caboni M. F. (2004). Antioxidant phenols in barley (Hordeum vulgare L.) flour: comparative spectrophotometric study among extraction methods of free and bound phenolic compounds. Journal of Agricultural and Food Chemistry, 52, 5195-5200.

Cabral, I. S. R., Oldoni, T. L. C., Prado, A., Bezerra, R.M.N., Alencar, S. M. \& Ikegaki, M. (2009). Composição fenólica, atividade antibacteriana e antioxidante da própolis vermelha brasileira. Quimica Nova, 32, 1523- 1527.

Clinical and Laboratory Standards Institute (CLSI). Performance standards for antimicrobial susceptibility testing, 18 th informational supplement M100-S18. Wayne, PA, USA (2008).

Clutterbuck A. L., Woods E. J., Knottenbelt D. C., Clegg P. D., Cochrane C. A. \& Percival S. L. (2007). Biofilms and their relevance to veterinary medicine. Veterinary Microbiology, 121(1/2):1-17.

Contreras, A., Corrales, J. C., Sànchez, A. \& Sierra, D. (1997). Persistence of caprine intramammary pathogens throughout lactation. Journal of Dairy Science, $80,2815-2819$.

Deinhofer, M. \& Pernthaner, A. (1995). Staphylococcus spp. as mastitis-related pathogens in goat milk. Veterinary Microbiology, $43,161-166$.

Diarra, M. S., Block, G., Rempel, H., Oomah, D. B., Harrison,J., Mccallum,J., Boula nge, S., Brouillette, E., Gattuso, M. \& Malouin, F. (2013). In vitro and in vivo antibacterial activities of cranberry press cake extracts alone or in combination with $\beta$-lactams against Staphylococcus aureus. BMC Complement. Alternative Medicine Review, 13, 90-114.

Ebrahimi, A., Soleimani, F., Moatamedi, A., Shams, N. \& Lotfalian, S. (2014). Study on some characteristics of Staphylococci isolated from sheep sub clinical mastitis milk in Shahrekord, Iran. Biological Journal of Microorganism, 2(8), 57-62.

Farshad, S., Ranijbar, R., Japoni, A., Hosseini, M., Anvarinejad, M. \& Mohammadzadegan, R. (2012). Microbial susceptibility, virulence factors, and plasmid profiles of uropathogenic Escherichia coli strains isolated from children in Jahrom, Iran. Archives of Iranian Medicine, 15(5), 312-316.

Fischer, G., Paulino, N., Marcucci, M., Siedler, B., Munhoz, L., Finger, P., Vargas, G., Hubner, S., Vidor, T. \& Roehe, P. (2010). Green propolis phenolic compounds act as vaccine adjuvants, improving humoral and cellular responses in mice inoculated with inactivated vaccines. Memórias do Instituto Oswaldo Cruz, 105, 908-913

Haenlein, G. F. W. (2001). Past, Present, and future perspectives of small ruminant dairy research. Journal of Dairy Science, 84, $2097-2115$.

Ismail, Z. B. \& Abutarbush, S. M. (2020). Molecular characterization of antimicrobial resistance and virulence genes of Escherichia coli isolates from bovine mastitis. Veterinary World, 13(8), 1588-1593.

Jaguezeski, A. M., Perin, G., Crecencio, R.B. et al. (2018) Addition of Curcumin in Dairy Sheep Diet in the Control of Subclinical Mastitis. Acta Scientiae Veterinariae, 46, 297

Kubilene, L., Laugaliene, V., Pavilonis, A., Maruska, A., Majiene, D., Barcauskaite, K., Kubilus, R., Kasparaviciene, G. \& Savickas, A. (2015). Alternative preparation of própolis extracts: comparison of their composition and biological activities. BMC Complementary and Alternative Medicine, 15(156), 1-7.

López, D., Vlamakis, H. \& Kolter, R. (2010). Biofilms. Cold Spring Harbor Perspectives in Biology and Medicine, 2(7), 1-11.

Lu, L. C., Chen, Y. W. \& Chou, C. C. (2005). Antibacterial activity of propolis against Staphylococcus aureus. International Journal of Food Microbiology, $102,213-20$.

Markey, B., Leonard, F., Archambault, M., Cullinane, A. \& Maguire, D. (2013). Clinical Veterinary Microbiology. (2nd ed.), Mosby Elsevier.

Messerli, S., Ahn, M., Kunimasa, K., Yanagihara, M., Tatefuji, T., Hashimoto, K., Mautner, V., Uto, Y., Hori, H. \& Kumazawa. S. (2009). Artepillin C (ARC) in Brazilian green propolis selectively blocks oncogenic PAK1 signaling and suppresses the growth of NF tumors in mice. Phytotherapy Research, 23, 423427.

Miorin, P. L., Levy Jr. N. C., Custodio, A. R., Bretzi, W. A. \& Marcucci, N. C. (2003). Antibacterial activity of honey and propolis from Apis mellifera and Tetragonista angustula against Staphylococcus aureus. Journal of Applied Microbiology, 95, 913-20.

National Mastitis Council. (2004). Microbiological procedures for the diagnosis of bovine udder infection and determination of milk quality. (4th ed.). NMC, Verona.

Neto, S., et al. (2009). Susceptibility of Staphylococcus spp. isolated from milk of goats with mastitis to antibiotics and green propolis extracts. Letters in Drug Design \& Discovery, 6(1), 63-68.

Paulino, N., Abreu, S., Uto, Y., Koyama, D., Nagasawa, H., Hori, H., Dirsch, V., Vollmar, A., Scremin, A. \& Bretz, W. (2008). Anti-inflammatory effects of a bioavailable compound, Artepillin C, in Brazilian propolis. European Journal Pharmacology, 587, $296-301$.

Pereira, I. M., Andrade, L. A., Barbosa, M. R. V. \& Sampaio, E. V. S. B. (2002). Composição florística e análise fitossociológica do componente arbus tivoarbóreo de um remanescente florestal no agreste paraibano. Acta Botanica Brasilica, 16(3), 357-369.

Pereira, A. S., Shitsuka, D. M., Pereira, F. J. \& Shitsuka R. (2018). Methodology of cientific research. UFSM Editors. https://repositorio.ufsm.br/bitstream/handle/1/15824/Lic_Computacao_Metodologia-Pesquisa-Cientifica.pdf?sequence=1 .

Pinheiro Junior, J. W., Oliveira, A. A. F., Alves, F. S. F., Silva, L. B. G., Rabelo, S. S. S. \& Mota, R. A. (2006). Corynebacterium pseudotuberculosis experimental infection of goats mammary gland. Arquivos do Instituto Biológico, 73(4), 395-400.

Pujirahayu, N., Ritonga, H. \& Uslinawaty, Z. (2014). Properties and flavonoids content in propolis of some extraction method of raw propolis. International Journal of Pharmacy and Pharmaceutical Sciences, 6(6), 338-40. 
Research, Society and Development, v. 10, n. 2, e18210211709, 2021

(CC BY 4.0) | ISSN 2525-3409 | DOI: http://dx.doi.org/10.33448/rsd-v10i2.11709

Radostits, O. M., Blood, D. C. \& Gay, C. C. (2000). Veterinary Medicine: A Textbook of the Diseases of Cattle, Sheep, Pigs, Goats and Horses. Saunders, Philadelphia.

Revers, L. M., Danielli, A. J., Ilchenco, S., Zeni, J., Steffens, C. \& Steffens, J. (2016). Obtenção e caracterização de iogurtes elaborados com leites de ovelha e de vaca. Revista Ceres, 63(6), 747-753.

Rohenkohl, J. E., Corrêa, G. F., Azambuja, D. F. \& Ferreira, F. R. (2011). O agronegócio de leite de ovinos e caprinos. Revista Indicadores Econômicos, 39, $97-114$.

Romanowsky, D. (1891). "Zur frage der parasitologie und therapie der malaria.". St Petersburg. Deutsche Medizinische Wochenschrift, 16, 307-15.

Rovai, M., Rusek, N., Caja, G., Saldo, J. \& Leitner, G. (2015). Effect of subclinical intrammamay infection on milk quality in dairy sheep: I. Fresh-soft cheese produced from milk of uninfected and infected glands and from their blends. Small Ruminant Research, 125, 127-136.

Santana, H. F., Barbosa, A. A. T., Ferreira, S. O. \& Mantovani, H. C. (2012). Bactericidal activity of ethanolic extracts of propolis against Staphylococcus aureus isolated from mastitic cows. World Journal of Microbiology Biotechnology, 28, 485-491.

Santos Neto, T. M., Mota, R. A., Silva, L. B. G., Viana, D. A., Lima-Filho, J. L., Sarubbo, L. A., Converti, A. \& Porto. A. L. F. (2009). Susceptibility of Staphylococcus sp. Isolated from Milk of Goats with Mastitis to Antibiotics and Green Propolis Extracts. Letters in Drug Design \& Discovery, 6, $63-68$.

Santos, F. A., Bastos, E. M. A., Uzeda, M. \& Carvalho, M. A. R. (2002). Antibacterial activity of Brazilian propolis and fractions against oral anaerobic bacteria. Journal of Ethnopharmacology, 80, 1-7.

Santos, R. A. et al. (2007). Aspectos clínicos e características do leite em ovelhas com mastite induzida experimentalmente com Staphylococcus aureus. Pesquisa Veterinária Brasileira, 27(1), 6-12.

Sforcin, J. M., Fernandes, J. R. A., Lopes, C. A. M., Bankova, V. \& Funari, S. R. (2000). Seasonal effect on Brazilian propolis antibacterial activity. J. Ethnopharmacol, 73, 243-249.

Souza, A. C. K. O., Osori, M., Osório, J., Oliveira, N., Souza, M. \& Correa, G. (2005). Produção, composição química e características físicas do leite de ovinos da raça Corriedale. Revista Brasileira de Agrociência, 11, 73-77.

Sperotto, V. D. R., Murari, A. L., Silva, D. A. R., Possenti, C. G. R., Wiest, J. M. \& Avancini C. A. M. (2012). Activity of the decoction of Achyrocline satureioides d.c. (Lam.) - asteraceae ("macela") against standard and isolated bacteria from bovine mastitis. Acta Science Veterinarie, $40,1052$.

Teixeira, E., Negri, G., Meira, R. (2005). Plant origin of green propolis: tumors in mice. Phytotherapy Research, 23, 423-427.

Wei, W., Dejie, L., Xiaojing, S., Tiancheng, W., Yongguo, C., Zhengtao, T., Naisheng, Z. (2015). Magnolol inhibits the inflammatory response in mouse mammary epithelial cells and mouse mastitis model. Inflammation, 38, 16-26.

Xu, Y., et al. (2009). Recent development of chemical components in propolis. Frontiers of Biology in China, 4(4), 385 